\title{
Evaluating The Groundwater Potential of Wadi Al- Jizi, Sultanate of Oman By Intergrating Remote Sensing \& GIS Techniques
}

\section{Javed Akhtar}

University of Petroleum and Energy Studies

\section{Ahmed Sana}

University of Petroleum and Energy Studies

Syed Mohammed Tauseef

University of technology and applied sciences

\section{Gajendran Chellaiah}

Karunya Institute of Technology and Sciences

\section{Parmeswari Kaliyaperumal}

Sultan Qaboos University

\section{Humayun Sarkar}

Sultan Qaboos University

Ramamoorthy Ayyamperumal ( $\nabla$ ramgeo.in07@gmail.com )

Lanzhou University https://orcid.org/0000-0002-7903-4267

\section{Research Article}

Keywords: Groundwater potential, Land use, Geology, Remote Sensing, GIS, Al-Batinah

Posted Date: August 24th, 2021

DOl: https://doi.org/10.21203/rs.3.rs-761541/v1

License: (c) (i) This work is licensed under a Creative Commons Attribution 4.0 International License. Read Full License 


\section{Abstract}

Groundwater resources are highly stressed due to their overuse, especially in the arid region. This study is aimed at discovering potential groundwater resource zones using currently available data and state-ofthe-art methods. This will lead to effective management of scarcely available and rapidly depleting groundwater resources in the Wadi Al-Jizi catchment, located in the Al-Batinah region. Data on terrain characteristics, geology, and geomorphology was integrated using remote sensing techniques and Geographical Information System (GIS). The result from this exercise was used for the identification of areas with a high potential for groundwater availability. These areas were classified into five types; namely; excellent, good, medium, low, and very low. The present study shows that the integration of all the weighted parameters shows promising results in the zonation of groundwater. This study shall be useful to the decision-makers in highlighting potential drilling as well as recharge sites in the area.

\section{Introduction}

Sultanate of Oman, with an average annual rainfall of $100 \mathrm{~mm}$, falls in the arid zone. The key source of freshwater is the precipitation in the mountainous area which results in the replenishment of the aquifers. Agriculture has grown tremendously over the last four decades due to the introduction of modern drilling and groundwater pumping systems. Due to the persistent water deficit caused by excessive pumping in the area, the water quality continues to deteriorate due to the intrusion of seawater. As a result, a number of farms have been abandoned and many others are currently facing salinity hazards. Over 50 percent of the country's cultivated land is located in Al-Batinah, which represents about $4 \%$ of the country's total area (Sana and Shibli 2006). Continuous population growth, climate change, heavy urbanization, and changes in land use have increased the thrust on the conventional surface water source to the extent that it has forced groundwater extraction as an alternative to surface water to cope with water scarcity (Banerjee et al. 2017, Gupta et al. 2019). An appreciable imbalance between the groundwater recharge and abstraction has resulted in groundwater deficit (Bahgwat et al. 2018). It is important to identify the areas which have a strong potential for groundwater, so that a balanced utilization and conservation strategy may be adopted for this precious water resource (Das et al. 2018). Some terrain features may indicate the presence of groundwater in sub-surface layers (Dinesan et al. 2015). The groundwater availability and dynamics depend on soil properties (soil type, porosity, hydraulic conductivity), terrain features (drainage pattern, topography, land-use), geologic and geomorphologic information (lithology, geological structure, depth of weathering, land-forms, fracture magnitude). In addition, climatic conditions and the interrelationship of all the above factors play a vital role in the presence and dynamics of groundwater (Dinesan et al. 2015, Sharma \& Shukla 2015).

In order to detect the availability, quantity, and quality of groundwater, the use of geophysics is very common. Such non-invasive methods help to map sub-surface geological structures and geological sequences. Akinlalu et al. (2017) employed a geophysical technique using Schlumberger configuration of electrodes. In the year 1992, geophysical exploration was carried out over an area of about 2000 square kilometers located in the eastern Al-Batinah region to demarcate fresh and saline water aquifers. (Young 
et al. 1998). The zones with groundwater potential were explored using the available geological and geophysical methods. Given the extensive and rigorous ground measurements required by these methods, they can only be used for large-scale mapping (Maity \& Mandal 2019, Suganthi et al. 2013). The ground survey forms an integral part of any conventional method used to gauge the groundwater potential (Al-Ruzouq et al. 2015, Yousuf et al. 2015).

In recent years, remote sensing and GIS have emerged as effective tools to synthesize all the available hydro-geological data and delineate potential groundwater occurrence zones. Using these methods, it is possible to delineate potential groundwater zone accurately. In addition, bias towards a single factor can be decreased. These methods are effective for exploring, analyzing, tracking, evaluating, and managing groundwater for sustainable groundwater utilization (AL-Ruzouq et al. 2015, Chaitanya et al. 2018, Das et al. 2018, Dinesan et al. 2015, Gunapuram et al. 2009, Gupta et al. 2019, Khan et al 2017, Machiwal et al. 2011, Mangesh et al. 2012, Nag \& Kundu 2018, Ramu 2014, Thakur et al. 2017, Thapa et al. 2017). Fashae et al. (2017) used multi-criteria decision analysis along with remote sensing and GIS methods to locate prospective groundwater areas in SW-Nigeria. For groundwater exploration, all the available thematic maps (soil, slope, geomorphology, lithology, land use, drainage density, topography, rainfall) are combined to identify a potential groundwater zone (Agrawal \& Garg 2016, Fashae et al. 2017, Thapa et al. 2017). Lubang et al. (2019) used a weighted index overlay technique created by Multi-Criteria Analysis to assigned the weights to the various map layers for his region of research to delineate Uganda's groundwater region. A simple mathematical model was used for the weighted index overlay analysis of multi-parameters (Sharma \& Shukla 2015). Selvam et al. (2015) used ArcGIS 9.3 software and used appropriate scores and weights based on the relative influence of the important parameters.

As the water table is lowered by pumping rates greater than the replenishment rates, the areas undergo a significant reduction in groundwater reservoir volumes that can lead to depletion of water in other water bodies (streams, lakes, and wells) and can cause land subsidence, deterioration of water quality and greater pumping expenses (Senanayake et al. 2016). As the volume of pumped water has increased and the water levels have declined, seawater intrusion takes place because of the adverse phreatic surface gradient. As a result, there has been a critical deterioration of groundwater quality. The supply of domestic water has declined as salinity has risen to concentrations which render the water unsuitable for human consumption. The crop yield has been affected, including the date palms that usually tolerate higher salinities. Groundwater stress is very high because of enormous demand and over-exploitation. As the salinity of the soil increased, farms were abandoned. 750 wells were abandoned in some part of AlBatinah, all within $6 \mathrm{~km}$ of the coastline. This emphasizes the urgent need for conservation measures to sustain this valuable wealth (MRMWR 2008). The present study is aimed at locating the potential areas for groundwater abstraction in a part of Al- Batinah using the most important factors such as soil, slope, geology, land use, and geomorphology.

\section{Study Area}


The Wadi Al-Jizi catchment is selected as the study area (located between Latitudes $2685288.72 \mathrm{~m} \mathrm{~N}$ to $2702809.30 \mathrm{~m} \mathrm{~N}$ and Longitudes $445120.53 \mathrm{~m}$ E to $474236.85 \mathrm{~m}$ E covered in a topographic map

(Figure.1). It is a coastal plain groundwater aquifer, located in the Al-Batinah region in northwestern Oman (Shibli 2002). The study area is bounded by the Sea of Oman on the north, while the Al Hajer Al Gharbi mountains range ais on the south. The rain falls in the Al-Batinah region's coastal belt between the months of October and April and as a consequence of thunderstorms in the foothills and hills during the month of July (MAF \& ICBA 2012). Wadi Al-Jizi catchment, with approximately $100 \mathrm{~mm}$ of average annual rainfall, is classified as arid. At higher altitudes in the catchment (1000 $\mathrm{m}$ and above) adjacent to mountains average annual rainfall is approximately $300 \mathrm{~mm}$ contributing to the coastal aquifer recharge (Young et al. 1998). The area is of vital importance to the Sultanate of Oman's agricultural economy and represents a large percentage of the agricultural products of the country. The primary source of freshwater that recharges the aquifer is mountain rainfall. The total the Wadi Al- Jizi catchment area is about $1,154 \mathrm{~km}^{2}$, including about $519 \mathrm{~km}^{2}$ of the east part. The aquifer system on the eastern part is studied that has an area of about $203 \mathrm{~km}^{2}$ extending from the sea towards the Wadi Al-Jizi dam having a capacity of $5.4 \mathrm{Mm}^{3}$.

\section{Material And Methods}

Five thematic layers, namely; slope, soil, land use, geomorphology, and geology are used in the present study. First thematic maps were generated and then analyzed for groundwater prospects. The following steps were followed in the study:

\section{Preparation of base map}

2. Digitization of thematic maps

3. Governing factors were given weightage based on their relative importance

4. Synthesis and use of thematic maps to gauge groundwater potential

The Ministry of Defense topographic map NG40-14F1 (1:50,000 scale) was used for the preparation of the base map. This base map was used to delineate the boundaries of basins, various natural features, and for georeferencing. The satellite image was analyzed visually to delineate soil lithological units and geomorphological units. Groundwater prospects maps were prepared using ArcGIS 9.0 software. Different thematic maps were allocated corresponding weights based on their impact on groundwater storage and movement (Sharma \& Shukla 2015). The weight of a variable reflects the percentage of its value in the prospective recharge scale. Since it is difficult to determine accurate recharge value for a large study area, the weight of the potential for recharge is estimated based on the significance of each factor during the recharge phase. The greater the weight of the recharge, the higher the impact factor. Each contributing factor has a degree of favorable or adverse impact in terms of groundwater recharge (Yeh et al. 2016). After assigning rank and weight to each thematic layer, the various thematic layers were 
overlaid using weighted overlay assessment. Agrawal and Garg (2016) used weight allocation to several thematic layers and the classes are based solely on the expert's decision.

\section{Results And Discussion}

Soil

The most vital natural resource for human habitation activities and farming is soil. It is primarily controlled by topographic conditions, climate, vegetative cover, and the parent rock (Nag and Kundu 2018). The infiltration rate depends on the soil conditions and the water percolation from the soil surface (Bahgwat et al. 2018). The topsoil in the study area is geologically unconsolidated and resulted from weathering of rocks. Figure 2 represents six types of soils found in the study area, that is, sandy gravel, coarse gravel, fine sand, silty clay, conglomerates, and sandy loam. Sandy gravel is the dominant type of soil covering about $50.4 \%$ of the study area. The coastal area consists of, mainly, silty clay with fine sand only along the coastline the porosity and permeability of the sand and gravel are high. Since infiltration rates of coarse-grained soils are high; so highest weight is assigned to these soils. Also, clayey soils have lower infiltration rates, therefore lower weights are allocated (El Hatim 1977, Rabu et al. 1993).

Slope

The surface gradient of the watershed directly influences rainfall infiltration. Steeper slopes allow less infiltration hence less recharge to the aquifer would result. In other words, a runoff would be rapid and therefore, the possibility of rainwater percolating from the surface is reduced (Mangesh et al. 2012, Yeh et al. 2016). A slope map was derived from the topographic map using Arc GIS. The slope varies from $0.0^{\circ}$ to more than $34.0^{\circ}$ as shown in Fig. 3. The study area has been classified with $97.75 \%$ of the area with a minimum slope range of 0 to $6^{\circ}$ and given the weightage of 4 , while the class with a maximum slope of $28-32^{\circ}$ covering an area of around $0.11 \%$ is assigned a weightage of 1 which is the lowest weightage used and indicates a lower possibility of groundwater occurrence (Agrawal \& Garg 2016).

\section{Geomorphology}

The geomorphology of a region relies on the structural evolution of the geological formation and reflects distinct structural features and land shapes. The structural features, as well as landforms, are identified and characterized using geomorphological maps. The groundwater movement and storage in a region depends on geomorphology as well (Chowdhary et al. 2019, Waikar and Nilawar 2014). Al-Batinah coastal plain, which is divided into two geomorphological units, is the hub for agriculture, industry, and settlement. The northern front of Al-Jabal Al-Akhdar is drained by a series of profoundly incised wadis that transform coastal terraces into gravel terraces, and finally, the coastal plain consisting of dispersed sabkhas, coastal sand dunes, fertile soil strips, and alluvial deposits (MRMWR, 2008).

The Ministry of Petroleum and Mineral, Oman Map was used to derive a geomorphology map using Arc GIS. Figure 4 shows the geomorphology of the study area. The area has the highest potential for 
recharge, mainly consists of wadi terraces and land-use farming. A significant amount of rainfall is allowed to percolate and reach subsurface layers. The geomorphological features in the area can be categorized into seven units such as active wadi channels, ancient alluvium, recent alluvium, sand dunes, khabra, sand veneers, and sabkha. The geomorphology of the study area is dominated by a unit of sand veneers covering $29 \%$ of the area. Khabra possessed an area of $20.9 \%$ followed by $19.4 \%$ and $18.7 \%$ shared by the active wadi channels and recent alluvium respectively, all of these have high water potential and therefore they have been assigned higher weights.

Land Surface characteristics

Land surface characteristics such as land cover and land use not only affect the groundwater recharge but also the microclimate. The mapped categories varied between map sheets depending on the surface characteristics (Chaitanya et al. 2018). The surface characteristics map (land-use and land-cover) depend on many factors like geomorphology, ecology, climatic conditions, and anthropogenic activities that significantly affect the groundwater occurrence and distribution (Chowdhary et al. 2019). Water bodies, cultivated land, and saturated surface are very efficient groundwater recharge sources, whereas the area affected by urban development is considered less effective. Hence, the highest weight is given to water bodies and the lowest to the built area (Agrawal and Garg 2016). Land-use and land-cover data for the study area were mapped using Google Earth (Digital Globe) rectified through ENVI 4.0, image processing software, and a topographic map. The most prevalent land-use in the study area is registered as an open space (71.9\%), plantation (12.7\%), and built-up area (14.8\%) as shown in Fig. 5. Reservoir dam had occupied least of the study area. The constructed area such as concrete surfaces, roads, and buildings that do not contribute to infiltration of the water were assigned least weightage, whereas, plantation area which plays a major role in recharge was given the highest weight.

\section{Geology}

The geology map of the study area is shown in Fig. 6 which has been prepared from the report published by the Ministry of Regional Municipalities and Water Resources. The alluvial plain of Al-Batinah lies at the base of alluvial fans. The remains of older fans are found as terraces of fluvial origin consisting of variable cemented rock beds, gravel, and sand. The primary aquifers presently utilized are high permeability wadi gravels and storativity (up to $50 \mathrm{~m}$ thick) and engraved into the terraces. Alluvial channels feed the coastal plain alluvium with water from the mountains. Wadi fans spread across the northern margin terraces and merge into the coastal plain's alluvium. The study has been widely covered by the alluvium possessed more than $97 \%$ of the area and assigned higher weight owing to its groundwater recharge capacity. In the coastal plain alluvium, three zones are traditionally acknowledged in reducing order of storativity and permeability: upper gravels; clayey gravels; and basal cemented gravels. The upper gravels which is the most productive unit are made up of flood-flow deposited sands, clean uncemented gravel, and boulder beds. The clayey gravels consist of clay bands coupled with gravel beds and calcareous material (Young et. al, 1998). The cemented gravel is the least permeable of the three units, but there may be a higher potential for uncemented fields in this region. All the available 
literature and data regarding the study area were used to assign suitable weights to thematic maps and their individual characteristics as shown in Table 1. 
Table 1

Weightage and ranks of various factors for groundwater potential zone

\begin{tabular}{|c|c|c|}
\hline Factors & Weightage & Rank \\
\hline Geomorphology & 20 & \\
\hline Active wadi & & 4 \\
\hline Recent alluvium & & 4 \\
\hline Ancient alluvium & & 1 \\
\hline Sabkha & & 3 \\
\hline Khabra & & 3 \\
\hline Sand veeneers & & 2 \\
\hline Sand dunes & & 5 \\
\hline Slope & 15 & \\
\hline Low & & 5 \\
\hline Gentle & & 4 \\
\hline Moderate & & 3 \\
\hline High & & 2 \\
\hline Very High & & 1 \\
\hline Geology & 30 & \\
\hline Alluvium & & 5 \\
\hline Hawasinah & & 3 \\
\hline Soil & 20 & \\
\hline Coarse gravel & & 4 \\
\hline Sandy gravel & & 5 \\
\hline Sandy loam & & 5 \\
\hline Silty clay & & 3 \\
\hline Fine sand & & 5 \\
\hline Conglomerates & & 1 \\
\hline Land use & 15 & \\
\hline Plantation & & 5 \\
\hline
\end{tabular}




\begin{tabular}{|lll|}
\hline Factors & Weightage & Rank \\
\hline Dam & 4 \\
\hline Open space & 3 \\
\hline Built up area & 2 \\
\hline
\end{tabular}

Groundwater potential zoning

Groundwater potential zones, as shown in Fig. 7, were generated by overlaying weighted reclassified raster map layers of Geology, geomorphology, soil, land use, land-cover, and slope in Arc-GIS. Table 2 presents the different classes of groundwater probabilities distributed in the study area. The result reveals that the dissemination of groundwater prospects in Wadi Al-Jizi covered $11 \%$ of the study area under the 'excellent' class, whereas the area having a class of 'medium' water potential is nearly $26 \%$. Most of the study area falls in 'good' (59.8\%). The pockets of 'low' and 'very low' zones, lying near the mountains covered less than $3.5 \%$ of the total evaluated area. Four groundwater recharge dams were constructed in the region to catch surface water that would otherwise flow into the sea or is lost by evaporation and is to allow infiltrating into the ground where it will augment existing groundwater supplies. Wadi Al-Jizi dam constructed in 1989 is one of them which can retain more than $116 \mathrm{MCM}$ of water also helping in enhancing the groundwater potential. Geomorphological units like active wadi channels and the latest alluvium are potential areas in the research area for groundwater exploration and growth. Wells are the most widely used means of supplying water for irrigation in Oman. As per MWR (2001), a total of 44502 wells were dug in the six wilayat of the region out of which 11331 wells were dug in Sohar wilayat. In the coastal plains, soils are particularly fertile, most of the water is used for agricultural purposes $(86 \%)$, followed by drinking water (12\%) and industrial use (2\%). Desalination provides only a small percentage of water, most of the water need is met through hand-dug and drilled wells for extraction of local groundwater.

Table 2

Rank and weightage of

various factors for

groundwater potential

zone

\begin{tabular}{|ll|}
\hline Class & Weightage \\
\hline Excellent & 5 \\
\hline Good & 4 \\
\hline Moderate & 3 \\
\hline Low & 2 \\
\hline Very low & 1 \\
\hline
\end{tabular}


An integrated approach based on remote sensing and GIS is used to locate the most suitable groundwater abstraction zones in the Wadi Al-Jizi catchment. This approach can help identify potential groundwater zones quickly and can be used in the study area as a guideline for integrated management of water resources. After identifying the suitable sites, detailed ground hydrogeologic investigations can be carried out to select the most suitable location for the sustainable abstraction of groundwater. This will also help in formulating an efficient and sustainable groundwater management plan for the management authorities and decision-makers concerned.

\section{Declarations}

\section{Ethics approval}

Not applicable

\section{Consent to participate}

Not applicable

\section{Consent to Publish}

Not applicable

\section{Authors' contributions}

JA: Conceptualization-Original draft, program running. AS: Writing-review \& editing, supervision, SMT: Data curation \& Data validation and Software, GC: Data Curation, software, review \& editing. PK: Data curation HS: Software \& Data curation, RA: Data validation \& review and editing.

\section{Funding}

Not Applicable

\section{Competing interests}

The authors declare no competing interests.

\section{Data availability}

The manuscript and data are the authors' original work, and the manuscript has not received prior publication and is not under consideration for publication elsewhere. The manuscript now submitted is not a copied or plagiarized version of some other published work.

\section{Acknowledgements}


The authors acknowledge the help of Ministry of Defense (MOD) and Ministry of Regional Municipality and Water Resources (MRMWR), Oman for providing required information.

\section{References}

1. Akinlalu AA, Adegbuyiro A, Adiat KAN, Akeredolu BE, Lateef WY (2017) Application of multi-criteria decision analysis in prediction of groundwater resources potential: A case of Oke-Ana, llesa Area Southwestern, Nigeria. NRIAG J Astron Geophys 6:184-200

2. Agarwal R, Garg PK (2016) Remote Sensing and GIS Based Groundwater Potential \& Recharge Zones Mapping Using Multi-Criteria Decision-Making Technique. Water Resour Manag 30:243-260

3. Al-Fouzan F, Dafalla MA, Al-Harbi A (2013) Evaluation of Cavity Formation and the Use of Cut-off Wall to Reduce the Risk of Washing Subsurface Fine Material. Open Journal of Geology 3:71-76

4. Al-Ruzouq R, Shanableh A, Merabtene T (2015) Geomatics for mapping of groundwater potential zones in northern part of the United Arab Emiratis - Sharjah City, The International Archives of the Photogrammetry, Remote Sensing and Spatial Information Sciences, Volume XL-7/W3, 36th International Symposium on Remote Sensing of Environment, 11-15 May 2015, Berlin, Germany

5. Banerjee A, Singh P, Pratap K (2017) Morphometric evaluation of Swarnrekha watershed, Madhya Pradesh, India: an integrated GIS-based approach. Applied Water Science 7:1807-1815. DOI 10.1007/s13201-015-0354-3

6. Bhagwat TN, Hegde VS, Shetty A (2018) Application of remote sensing and GIS for identification of potential ground water recharge sites in Semi-arid regions of Hard-rock terrain, in North Karnataka, South India. Sustainable Water Resources Management. DOI 10.1007/s40899-018-0244-6

7. Chaitanya B, Pande CB, Khadri SFR, Moharir KN, Patode RS (2018) Assessment of groundwater potential zonation of Mahesh River basin Akola and Buldhana districts, Maharashtra, India using remote sensing and GIS techniques. Sustainable Water Resources Management 4:965-979

8. Chitrakar P, Sana A (2015) Ground water flow and solute transport simulation in eastern Al Batinah coastal plain, Oman: Case study, Journal of hydrologic engineering, ASCE.ISSN: 1084 0699/050150020(11)

9. Chowdhury SJ, Rahaman M, Riad A, Ali MS, Mazumder QH (2019) Delineation of groundwater potential zones of Atrai-Sib river basin in north-west Bangladesh using remote sensing and GIS techniques. Sustainable Water Resources Management 5:689-702

10. Das B, Pal SC, Malik S, Chakrabortty R (2018) Modeling groundwater potential zones of Puruliya district, West Bengal, India using remote sensing and GIS techniques, Geology, Ecology, and landscapes, https://doi.org/10.1080/24749508.2018.1555740

11. Dinesan VP, Girish G, Ashitha MK (2015) Application of Geoinformatics for the Delineation of Groundwater Prospects Zones- a Case Study for Melattur Grama Panchayat in Kerala, India. Aquatic Procedia 4:1389-1396 
12. Hatim El Attar H (1977) Development of New Land for Irrigated Agriculture in Oman -Soil and Land Classification-A Soil Consultant report to Ministry of Agriculture. Fisheries, Petroleum and Minerals Directorate of Agriculture

13. Fashae OA, Tijani MN, Talabi AO, Adedeji OI (2014) Delineation of groundwater potential zones in the crystalline basement terrain of SW-Nigeria: an integrated GIS and remote sensing approach. Appl Water Sci 4:19-38. DOI 10.1007/s13201-013-0127-9

14. Ganapuram S, Vijaya K G GT, Krishna T, Kahya M, Cüneyd E D M (2009) Mapping of groundwater potential zones in the Musi basin using remote sensing data and GIS. Adv Eng Softw 40:506-518

15. Gupta R, Mishra AK, Sahu V (2019) Identification of watershed preference management area under water quality and scarcity constraints: case of Jhajjar district watershed, India. Applied Water Science 9:27. https://doi.org/10.1007/s13201-019-0905-0

16. Khan A, Khan H, Umar R (2017) Impact of land-use on groundwater quality: GIS-based study from an alluvial aquifer in the western Ganges basin. Applied Water Science 7:4593-4603. https://doi.org/10.1007/s13201-017-0612-7

17. Lakey R, Easton P, Hinai AH (1995) Eastern Batinah Water Resources Assessment- The International Conference on Water Resources Management in Arid Countries Proceedings. Muscat. Sultanate of Oman. The library of the General Directorate of Regional Municipality, Environment and Water Resources in North of Al-Batinah, Sohar, Oman

18. Lubang B, Nobert J. Mtalo EG (2019) Integrated Remote Sensing and GIS Techniques for Groundwater Exploration in Semi-Arid Region: A Case of Karamoja Region - Uganda, https://www.researchgate.net/publication/332528494

19. Machiwal D, Jha MK, Mal BC (2011) Assessment of Groundwater Potential in a Semi-Arid Region of India Using Remote Sensing, GIS and MCDM Techniques. Water Resour Manage 25:1359-1386. DOI 10.1007/s11269-010-9749-y

20. Magesh NS, Chandrasekar N, Soundranayagam JP (2012) Delineation of groundwater potential zones in Theni district, Tamil Nadu, using remote sensing, GIS and MIF techniques. Geosci Front $3(2): 189-196$

21. Maity DK, Mandal S (2019) Identification of groundwater potential zones of the Kumari river basin, India: an RS \& GIS based semi-quantitative approach. Environmental Development Sustainable 21:1013-1034,. https://doi.org/10.1007/s10668-017-0072-0

22. Ministry of Agriculture and Fisheries (MAF) and International Center for Biosaline Agriculture (ICBA) (2012) Oman Salinity Strategy - Assessment of Salinity Problem: Annex-1, Muscat. Sultanate of Oman

23. Ministry of Regional Municipality \& Water Resources (MRMWR) (2008) Water Resources in Oman Report issued on the Occasion of the Expo Zaragoza 2008, Sultanate of Oman

24. Ministry of Water Resources (MWR) (2001) Aflaj Inventory Project Summary Report, The library of the General Directorate of Regional Municipality. Environment and Water Resources in North Al Batinah, Sohar

Page $12 / 21$ 
25. Nag SK, Kundu A (2018) Application of remote sensing, GIS and MCA techniques for delineating groundwater prospect zones in Kashipur block, Purulia district, West Bengal. Applied Water Science 8:38,. https://doi.org/10.1007/s13201-018-0679-9

26. Pinto D, Shrestha S, Babel MS, Ninsawat S (2017) Delineation of groundwater potential zones in the Comoro watershed, Timor Leste using GIS, remote sensing and analytic hierarchy process (AHP) technique. Applied Water Science 7:503-519. DOI 10.1007/s13201-015-0270-6

27. Rabu D, Nehlig P, Roger J, Bechennec F, Beurrier M, Le M, our J. Bourdillon de Grissac C, Tegyey M, Chauvel JJ, Cavelier C, Al Azri H, Juteau T, Janjou D, Lemitre B, Villey M, Wyns R (1993) Stratigraphy and structure of the Oman mountains. Document du BRGM 221:262 pp

28. Ramu, Mahalingam B, Vinay M (2014) Identification of ground water potential zones using GIS and Remote Sensing Techniques: A case study of Mysore taluk - Karnataka. International Journal of Geomatics Geosciences 5(3):393-403

29. Sana A, Al-Shibli SH (2006), "Numerical modeling of seawater intrusion into coastal aquifers in Sultanate of Oman", Regional Conference on Groundwater Protection, Tripoli, Libya

30. Selvam S, Dar FA, Mangesh NS, Singaraja C, Venkatramanan S, Chung SY (2015) Application of remote sensing and GIS for delineating groundwater recharge potential zones of Kovilpatti Municipality, Tamil Nadu using IF technique. Earth Sci Inf. DOI:10.1007/s12145-015-0242-2

31. Senthil KGR, Shankar K (2014) Assessment of Groundwater Potential Zones Using GIS, Frontiers in Geosciences, FG Volume 2, Issue 1 Jan. 2014 PP. 1-10 www.fg.org @ American V-King Scientific Publishing

32. Senanayake IP, Dissanayake D M D O K, Mayadunna BB, Weerasekera WL (2016) An approach to delineate groundwater recharge potential sites in Ambalantota, Sri Lanka using GIS techniques. Geosci Front 7:115-124

33. Sharma AK, Shukla JP (2015) A Remote Sensing and GIS Based Approach to Evaluate the Ground Water Prospects of Baghain Watershed, Panna and Satna Districts of M.P., India: A Case Study, Journal Geological Society of India Vol.86, December 2015, pp.733-741

34. Shaikh N, Rukhsana, Sarkar H (2013) Groundwater modeling: RS and GIS Perspective: Groundwater zone prediction, LAP LAMBERT Academic Publication, ISBN: 978-3-659-48730-9

35. Shibli SH (2002) Modeling of Saltwater Intrusion in Wadi Al-Jizi Aquifer, Master's Thesis, SQU, Sultanate of Oman

36. Singh P, Thakur JK, Singh UC (2013) Morphometric analysis of Morar river basin, Madhya Pradesh, India, using remote sensing and GIS techniques. Environmental Earth Science Springer 68:19671977. DOI 10.1007/s12665-012-1884-8

37. Suganthi S, Elango L, Subramanian SK (2013) Groundwater potential zonation by Remote Sensing and GIS techniques and its relation to the Groundwater level in the Coastal part of the Arani and Koratalai River Basin, Southern India. Earth Sci Res SJ Vol 17(2):87-95

38. Thakur JK, Singh SK, Ekanthalu VS (2017) Integrating remote sensing, geographic information systems and global positioning system techniques with hydrological modeling. Applied Water 
Science 7:1595-1608. DOI 10.1007/s13201-016-0384-5

39. Thapa R, Gupta S, Guin S, Kaur H (2017) Assessment of groundwater potential zones using multiinfluencing factor (MIF) and GIS: a case study from Birbhum district, West Bengal. Applied Water Science 7:4117-4131. DOI 10.1007/s13201-017-0571-z

40. Waikar ML, Nilawar AP (2014) Identification of Groundwater Potential Zone using Remote Sensing and GIS Technique, International Journal of Innovative Research in Science,Engineering and Technology, Vol. 3, Issue 5, ISSN: 2319-8753

41. Weyhenmeyer CE, Stephen JB, Niklaus WH (2002) Isotope study of moisture sources, recharge areas, and groundwater flow paths within the Eastern Batinah coastal plain, Sultanate of Oman, Water Resour Res, 38, 10, 1184, DOI:10.1029/2000WR000149

42. Yeh HF, Cheng YS, Lin HI, Lee CH (2016) Mapping groundwater recharge potential zone using a GIS approach in Hualian River, Taiwan. Sustainable Environment Research 26:33-43

43. Young ME, Bruign RGM, Al Ismaily AS (1998) Exploration of an alluvial aquifer in Oman by timedomain electromagnetic sounding. Hydrogeol J 6:383-393

44. Yousef AH, Priju CP, Narasimha Prasad NB (2015) Delineation of Groundwater Potential Zones in Deep Midland Aquifers along Bharathapuzha River Basin, Kerala using Geophysical Methods, International Conference On Water Resources, Coastal And Ocean Engineering, Aquatic Procedia 4, pp.1039-1046

\section{Figures}




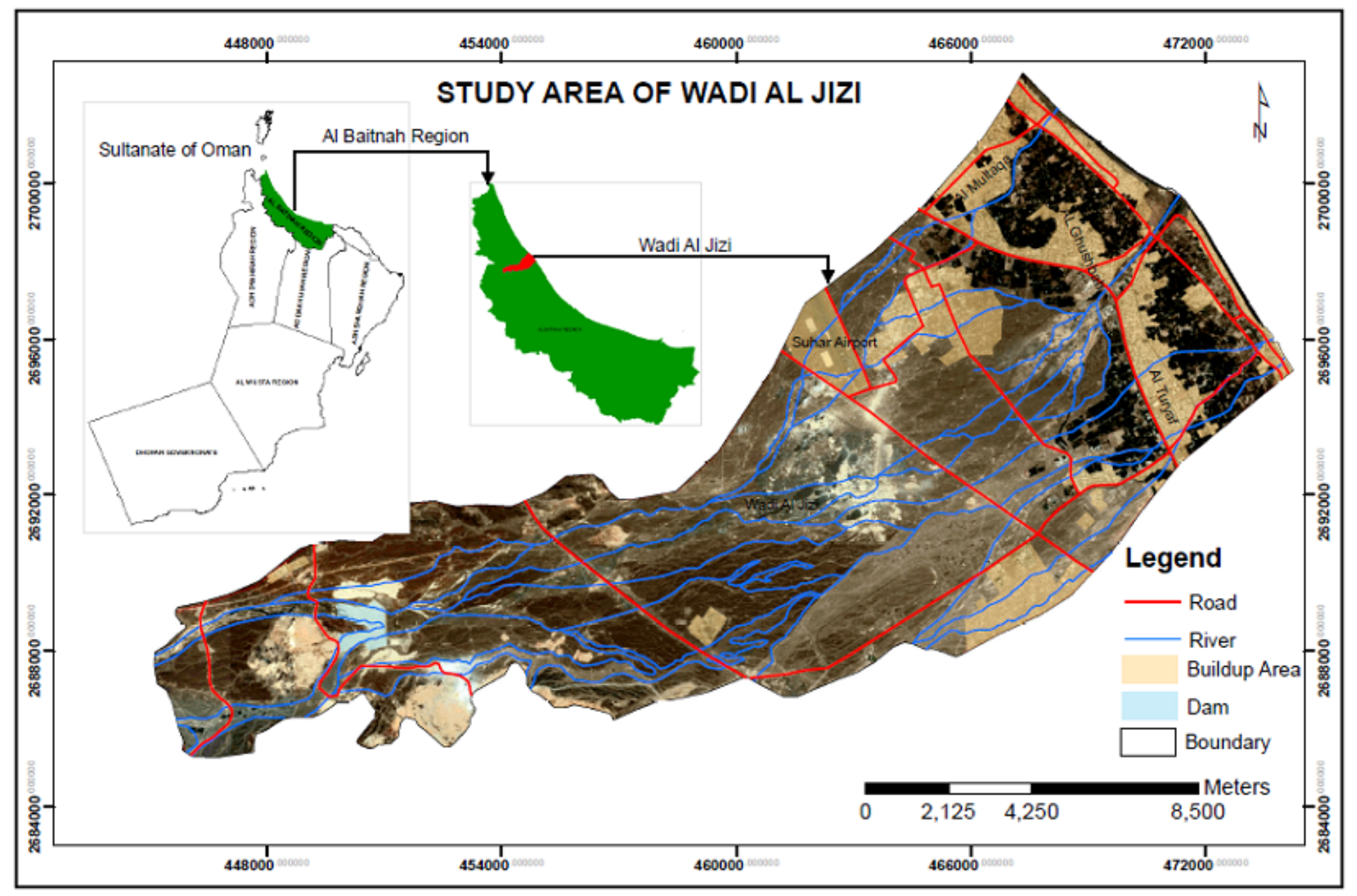

Figure 1

Location map of study area of Wadi Al-Jizi 


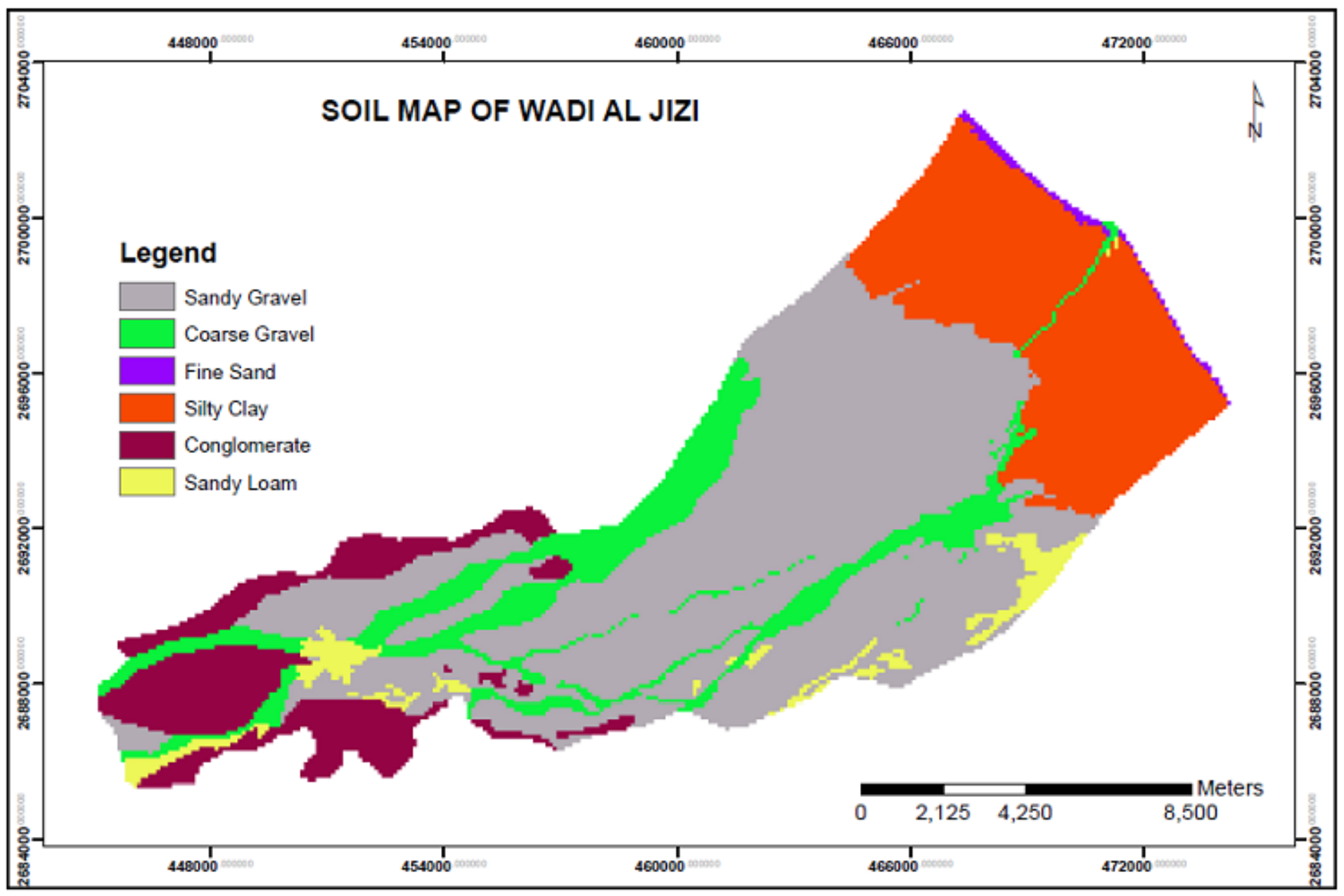

Figure 2

Soil Map of the study area 


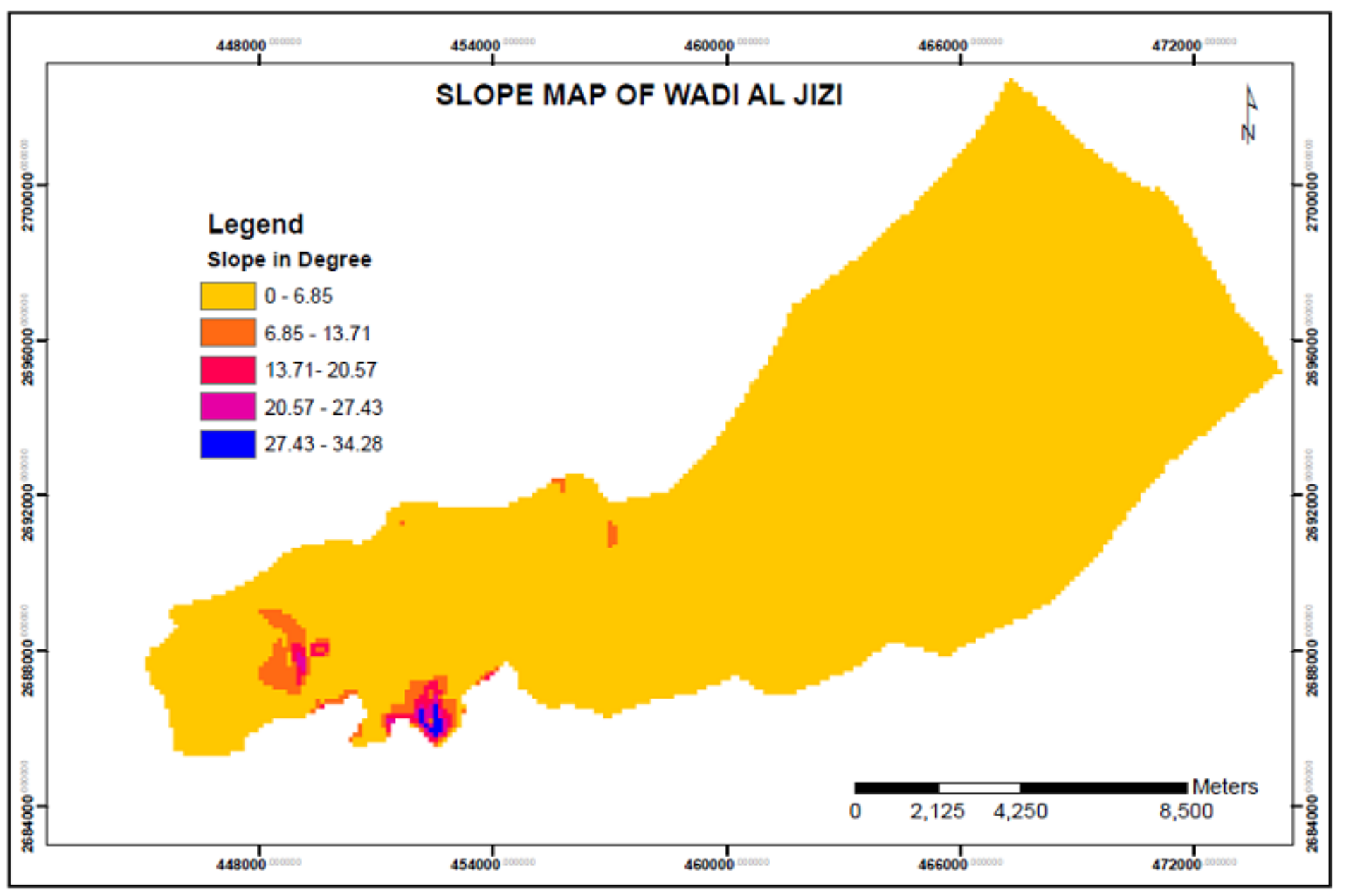

Figure 3

Slope Map of the study area 


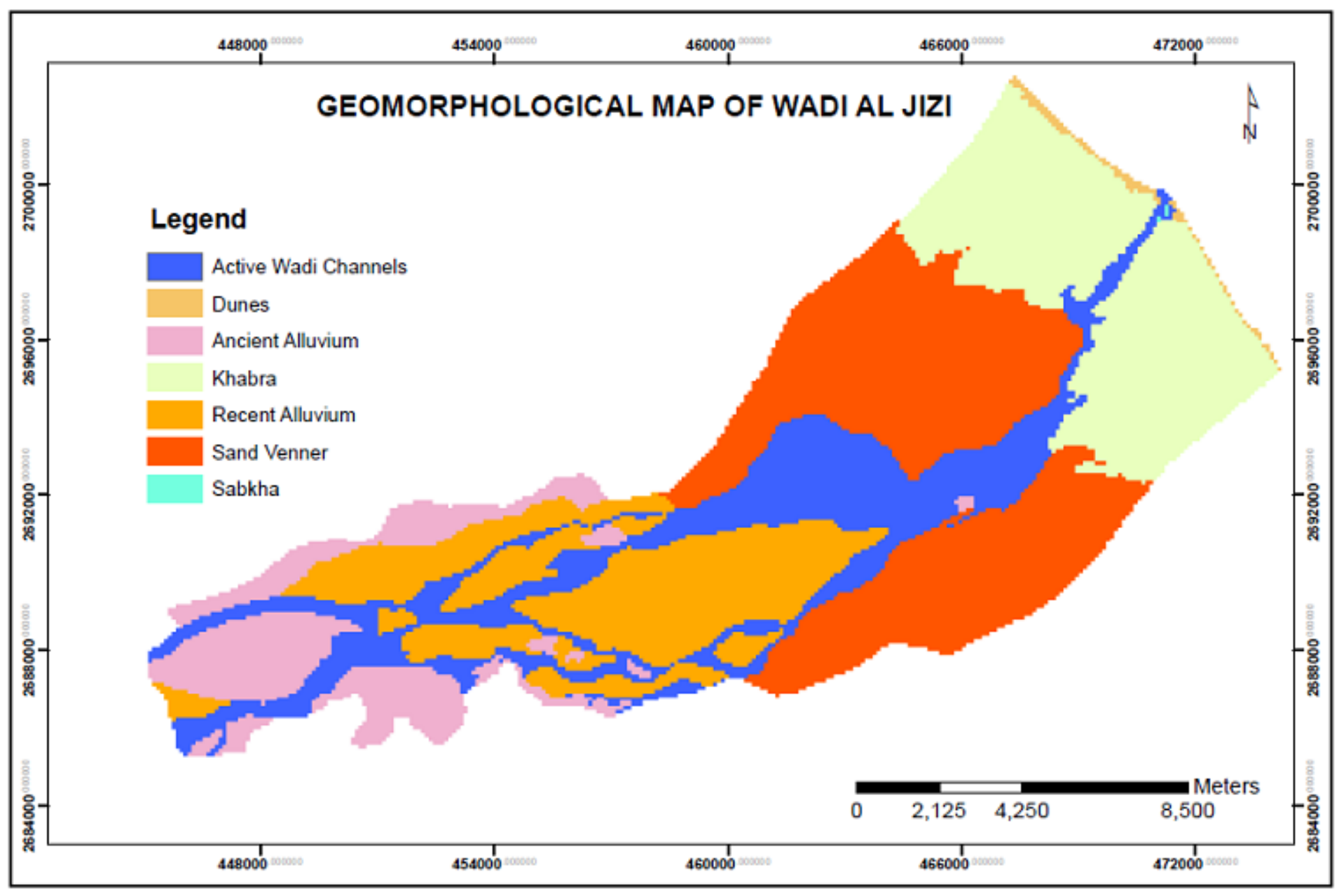

Figure 4

Geomorphology of the study area 


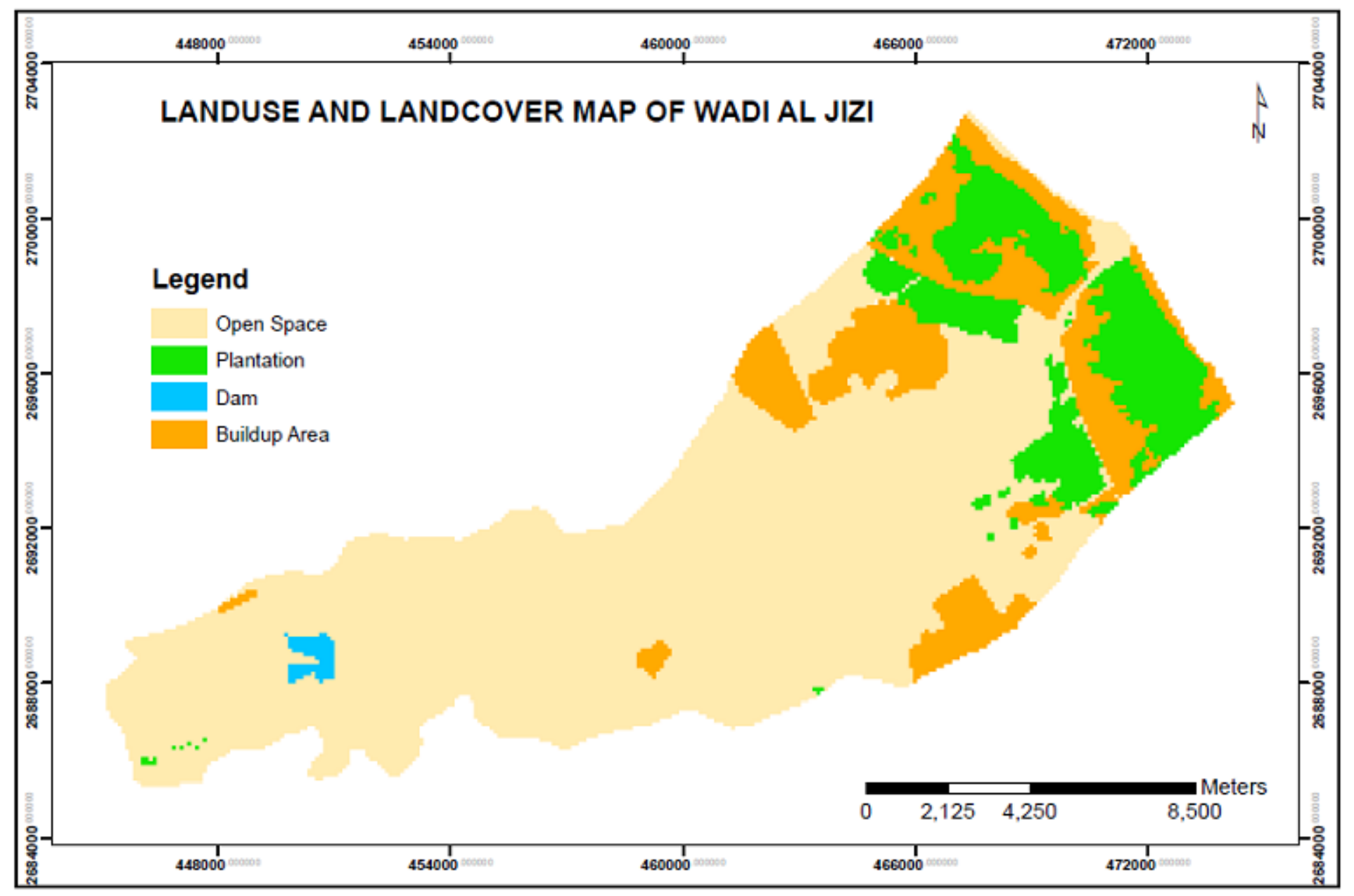

Figure 5

Land use /Land cover map of the study area 


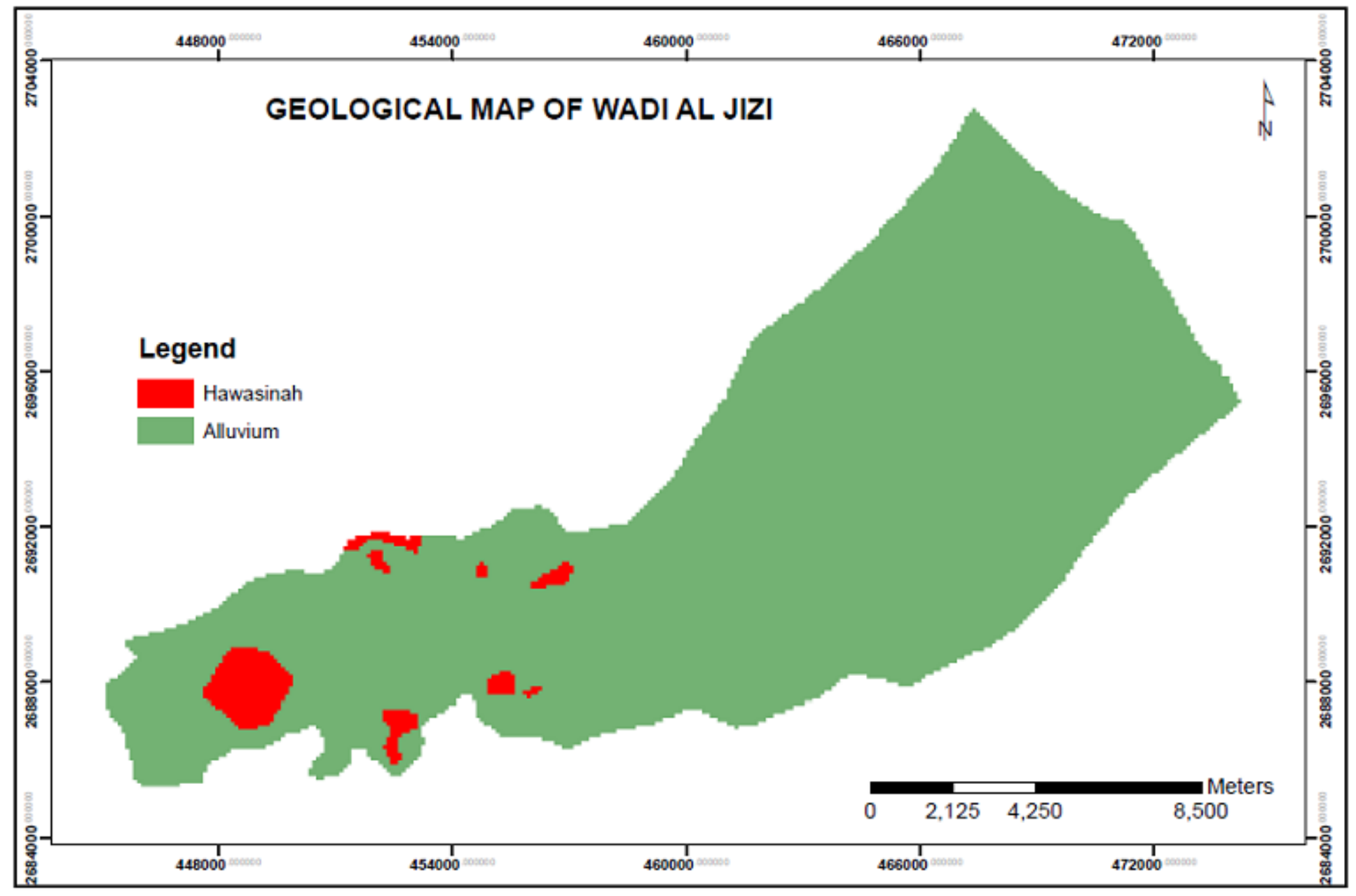

Figure 6

Geology map of the study area 


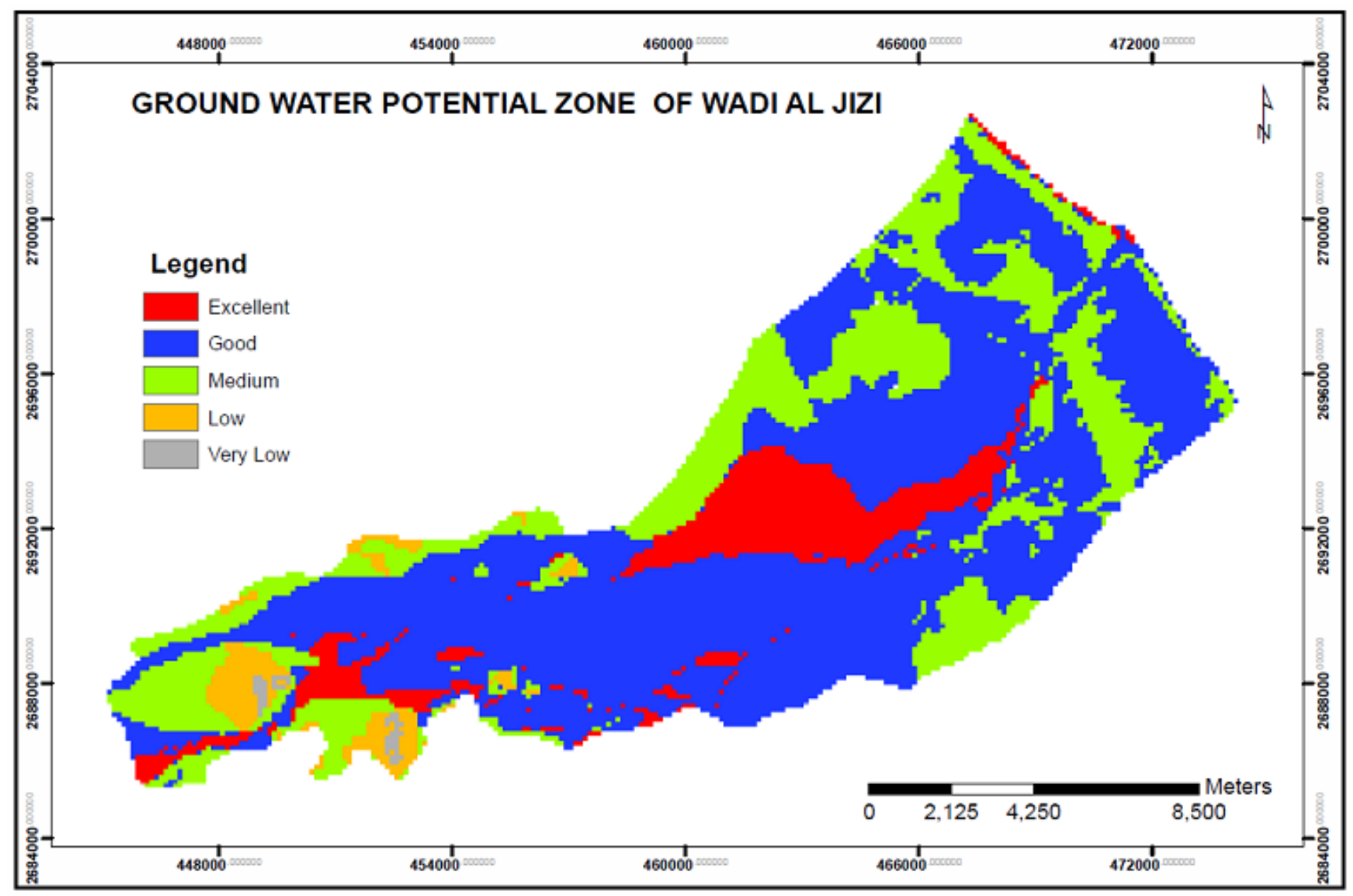

Figure 7

Ground water potential zones of the study area 